\title{
The Post-Soviet Politics of Utopia: Language, Fiction and Fantasy in Modern Russia
}

\author{
Mikhail Suslov \& Per-Arne Bodin (red.) \\ London: Tauris 2020 \\ 362 sider. ISBN: 9781788312288
}

Anmeldt av Fabian Heffermehl [forsker, Institutt for litteratur, områdestudier og
europeiske språk, Universitetet i Oslo, fabian.heffermehl@ilos.uio.no]

Utopier slavebinder og utopier befrir. Mikhail Suslov og Per-Arne Bodin skriver at utopier «frigjør menneskehjernen fra døde generasjoners tradisjoner, fostrer fri flyt av fantasi, underminerer hegemoni og får oss til å tenke i alternativer» (s. 1, min oversettelse). Dermed settes russiske utopier inn i en rekke nye sammenhenger. Forordet trekker opp omfattende og viktige avgrensninger mellom litteratur og politikk. Mens for eksempel Boris Groys i Gesamtkunstwerk Stalin har hevdet at avantgardens prosjekter dannet en modell for den stalinistiske totaltransformasjonen av det russiske samfunnet, legger Suslov og Bodin opp til en mer nyansert fremstilling av utopienes kulturhistorie fra 1700-tallet fram til idag med hovedvekt på ikke-kanoniske litterære verker.

Innenfor en sovjetisk kontekst blir utopier hovedsakelig utforsket som science fiction, en sjanger skrevet av og for intelligentsiaen. Science fiction kombinerte teknologisk optimisme med det kommunistiske moderniseringsprosjektet, og utgjorde slik et instrument i det sovjetiske samfunnets selvrefleksjon. I Putins Russland er det derimot andre motivasjonsfaktorer og betydninger som gjør seg gjeldende. I større grad synes science fiction nå å gjenta problemstillinger fra 1800-tallets russiske identitetsdebatter. Det handler om auto-orientalisering, altså et forsøk på å forstå Russland som noe unikt og spesielt mellom vest og øst.

Utopier konsentrerer i seg geopolitiske myter og metaforer. Suslov og Bodin beskriver dette som et nei til smarttelefoner; ja til romraketter. Det er ikke det 21 . århundrets digitale teknologi som hovedsakelig opptar nåtidens russiske forfattere av science fiction. I stedet synes sjangeren å ta opp tråden fra den sovjetiske utforskningen av verdensrommet. Dermed løper utviklingen av science fiction parallelt med utviklingen av moderne russisk geopolitikk, for eksempel i ideen om deler av Ukraina som "det nye Russland», "Novorossija». Flere kapitler handler om hvordan litterære narrativer oppstår i kjølvannet av krigen i Ukraina. Felles for litteraturen og geopolitikken er at de gjenoppliver varianter av 1800-tallets imperialisme, og på 
denne måten vender seg bort fra postmoderne prinsipper om økonomisk åpne og samtidig politisk ukrenkelige grenser. Suslov og Bodins bok gir innsikt i de retrospektive aspektene ved dagens russiske kultur og samfunnsliv.

Et velskrevet, dyptpløyende forord følges opp av fire deler med til sammen fjorten essay av internasjonale forskere som reflekterer over forbindelsene mellom litteratur og samfunn i Russland. Bokens første del behandler forholdet til historien og hvordan forfattere i utopiske og dystopiske fremtidsscenarier har innarbeidet kontrafaktiske problemstillinger: Hva hvis oktoberrevolusjonen i 1917 aldri hadde funnet sted? Mens science fiction idag i stor grad orienterer seg mot Sovjetunionens teknologiske kvantesprang, blir revolusjonen 1917 - selve grunnhendelsen for Sovjetunionens tilblivelse - avvist som en ren gjentagelse av «den store forvirring» ("smuta» 1598-1613), altså en periode av forfall og splittelse. Bokens andre del handler om ideologi. Hvordan inkorporeres profetiske scenarier i ideen om Russland som en unik sivilisasjon? Kapitlene konsentreres rundt en rekke paradokser i putinismen, i samtidens russiske idé: Russland som et både unikt og universelt fenomen, og tradisjon og konservatisme som noe revolusjonært og utopisk. Eksemplene spenner fra Eduard Limonovs nonfiksjon som antiutopi til tekster hvor russisk ortodoksi nærmer seg utopisk eller dystopisk populærlitteratur. Bokas tredje del fokuserer på det russiske språkets betydning $i$ utopier og dystopier og henter eksempler blant annet fra russiske emigranters hybride identiteter og fra Valéry Votrins Logoped. Fantasier om det russiske språket og dets historie, kirkeslavisk osv., flettes inn i ideologiske debatter mellom konservative og liberale. Fjerde del handler om det russiske territoriets fantasmagori. Det russiske territoriet er blitt en ambivalent størrelse i litterære utopier. Territoriet er en kilde til både imperiale forhåpninger og fantomsmerter. I denne delen, som omhandler alt fra middelalderen i Vladimir Sorokins romaner til Dmitry Bykovs jernbanesymbolikk, viser forfatterne hvordan Sovjetunionens oppløsning er blitt et traume i samtidslitteraturen.

En av bokens interessante hovedteser - nei til smarttelefoner, ja til romraketter kan nyanseres videre. Boken gir et inntrykk av moderne russisk science fiction som noe nesten utelukkende retrospektivt; en slags type "retro-science-fiction", det vil si en forsinket reaksjon på Sovjetunionens teknologiske fremskritt. Suslov og Bodins bok avdekker viktige sider ved interaksjonen mellom konservatisme og fantasi i Russland. Men både i russisk samtid og litteraturhistorie kan også en rekke dagsaktuelle problemer i det 21. århundret - som klimakatastrofer, virtuelle nettverk og digitalisering - føres tilbake til ulike litterære tradisjoner. Det at alle forfatterne har slavistisk bakgrunn kan virke begrensende, dersom man i et bredere interdisiplinært (og internasjonalt) perspektiv stiller spørsmål ved de russiske utopienes aktualitet for å forstå samspillet mellom teknologi, kultur og politikk i det 21. århundret. Denne begrensningen kan imidlertid ikke avlede oppmerksomheten fra bokens kvaliteter: Alle kapitlene gir velskrevne, egenartede bidrag til det som boken har satt som sitt tema: science fiction og litteratur i Russland. For videre forskning på forholdene mellom politisk kultur, populærkultur og kulturpolitikk i Russland vil Suslov og Bodins bok ikke være til å unngå. Forskere med generell interesse for russisk samtidslitteratur vil her finne interessante teoretiske vinklinger og materialer. 